OPEN ACCESS

Edited by:

Laurent Dufossé,

Université de la Réunion, France

Reviewed by:

Maksim Rebezov,

Russian Academy of Sciences

(RAS), Russia

Heru Irianto,

Sebelas Maret University, Indonesia

${ }^{*}$ Correspondence:

Mária Holotová

maria.holotova@uniag.sk

Specialty section:

This article was submitted to

Sustainable Food Processing, a section of the journal

Frontiers in Sustainable Food Systems

Received: 30 April 2021

Accepted: 24 June 2021

Published: 20 July 2021

Citation:

Holotová M, Horská E and Nagyová L (2021) Changing Patterns of Sustainable Food Consumption Regarding Environmental and Social Impact-Insights From Slovakia.

Front. Sustain. Food Syst. 5:703827. doi: 10.3389/fsufs. 2021.703827

\section{Changing Patterns of Sustainable Food Consumption Regarding Environmental and Social Impact-Insights From Slovakia}

\author{
Mária Holotová*, Elena Horská and Ĺudmila Nagyová \\ Department of Marketing and Trade, Slovak University of Agriculture, Nitra, Slovakia
}

Food consumption accounts for almost one-third of households' total environmental impact. Nowadays, consumption patterns throughout Europe are totally different from those of couple years ago, Slovakia is no exception. At an individual level, people's consumption patterns are shaped by their needs, abilities and opportunities. Exploring and understanding consumers' attitudes toward sustainable food consumption tendences is a key element to a better future for every country. This paper presents an analysis of the current situation regarding sustainable food habits among Slovak consumers. The main aim is to determine the level of consumer awareness for sustainable food consumption and food waste through purchasing decisions. Marketing research was conducted as a part of European project in five partner countries, we present results for Slovakia. Based on the analysis, we will be able in future to define limitations and opportunities in the form of recommendations in future. The findings of this paper have significant contributions and may encourage the process for the discussions and to provide the basis for educational content to help adults develop their skills and behaviors to make food consumption more sustainable.

Keywords: consumer, food consumption, sustainability, food waste, Slovakia

\section{INTRODUCTION}

Sustainable consumption should be understood as a dynamic aspect, i.e., a consumption model that indicates the desired and necessary direction. It does not always mean quantitatively lower consumption, but rather the consumption of products in a different and especially smarter way. Sustainable consumption includes not only the minimization of consumption itself, but also its reorientation, in terms of a change in customer habits toward a more sustainable lifestyle and purchasing decisions (Vasilová, 2013). Other authors consider sustainable consumption attitude as an act of voluntary simplicity and anti-consumption (Black, 2010). Ecologically and socially responsible people demonstrate their environmental interests through their private consumption decisions (Lee, 2014). These decisions are fully influenced by the personal values of each consumer (Sener and Hazer, 2008; Sharma and Jha, 2017).

Food represents a major issue in sustainable production and consumption, with its great impact on the environment and the economy as well (Donati et al., 2016; Fanzo, 2019). The most serious environmental impacts from food occur at the beginning of the production chain, but households influence these impacts through their dietary choices and demand for food-related services. 
Households also directly affect the environment through foodrelated energy consumption and waste generation (Ivanova et al., 2015; Castellani et al., 2019).

A broad spectrum of foods is available in advanced countries because technical, economic and commercial developments have allowed it possible to supply with food throughout the year. Moreover, advances in production and globalization have enabled consumers in number of countries to benefit comparatively low prices and high convenience. Despite these facts, this convenience has come at a high cost to society. One of the consequences is that many consumers have stopped producing their own foods and forgotten about the benefits of regional, organic and seasonal foods (Blay-Palmer, 2008; Matharu et al., 2021). Sustainable consumption lifestyle cannot be ensured only through targeted education, supply of knowledge, or even through awareness; it calls for conscious habitforming based on voluntary, positive approach and engagement (Quoquab and Mohammad, 2017).

Verain et al. (2015) described in their work three extensive schemes as strategic paths to achieve the desired goal:

- options regarding the means of production (e.g., Fair-Trade products, free-range, and organic products)

- options regarding dietary composition and consumption reducing (limit the quantity) within some contentious product categories (e.g., in most advanced European countries, the reduced average consumption of some types of meat, heavily processed foods, and sweetened beverages)

- opportunities leading to the prevention of food wastage. First key role in systematic reduction is purchasing decision (buying short-dated items that would otherwise be discarded, meaningful and necessary food shopping and creative use of leftovers).

In determining the factors that influence purchasing decisions, it is wrong to assume that food consumption behavior is influenced primarily by physiological needs combined with purchasing power. Other important factors that enter the complex chain are as follows (Reisch et al., 2013; Khan et al., 2018):

- cultural stereotypes, norms,

- demographic characteristics of households,

- social media and lifestyle,

- time availability and household decision-making,

- convenience vs. sustainability.

We are witnessing various problems in adopting sustainable consumption. The current adoption process is extremely slow in relation to the critical need for change (Berčík and Gálová, 2013; Wang et al., 2014). One of important barrier is consider lack of awareness as consumers are often unaware of the negative impacts of their consumption habits. Social media and mass media could provide a great opportunity to transform the traditional consumer society, but their current focus in many cases corresponds to the opposite trend (McDonald et al., 2012; Malodia and Bhatt, 2019). The disinterest and negligence of people appears to be another problem in building sustainable patterns of behavior. In this case, the only driving force is to set certain societal norms that will force people to live a more sustainable lifestyle and protect the environment (Briceno and Stagl, 2006; Mont and Plepys, 2008). Another barrier is considered the cost associated with sustainable consumption, whether real or imagined (Quoquab and Mohammad, 2017). People are reluctant to give up their usual comforts, and such a change could in some ways mean sacrifice for higher ethical and moral goals (Verain et al., 2012).

Current and planned consumption patterns in households are influenced by a number of different drivers. Higher incomes, demography (more employed women, more single-member households, growing retirement population) and accompanying lifestyle changes have led to changes in more individual shopping and preference for processed and packaged products (Kalbar et al., 2018; Sharma et al., 2018). As the modern consumer spends less time on cooking, eating and makes impulsive and ill-considered food purchases over the last years, home-cooked meals have lost their significance, while semi-finished products, fast foods and restaurant meals have gained importance (Higgs and Thomas, 2016).

More importantly, consumers affect the environment with their nutrition styles and diets. For example, consumption of (red) meat and dairy products have today by far the highest GHG emissions (OECD, 2018). Tukker et al. (2006) claim that within the European Union, meat and meat products contribute to between 9 and $14 \%$ of total releases, followed by milk, cheese, and other dairy products. Livestock farming has a significantly higher carbon footprint than growing vegetables or fruit (Our World in Data, 2020). Animal agriculture, especially factory farming, is the largest contributor to several of the most urgent ecological crises of our time. It is estimated to be responsible for up to $17 \%$ of the EU's human-induced greenhouse gas emissions (Mihina et al., 2018; Csillag et al., 2019). The average EU citizen has a food footprint of $1,070 \mathrm{~kg}$ of $\mathrm{CO}_{2}$ - equivalent per year. The research, which was conducted in 2014 estimated that if the EU citizens ate $50 \%$ less meat, dairy products, and eggs, this would reduce agriculture greenhouse gas emissions by $25-40 \%$. This would represent significant progress toward meeting the EU target of cutting greenhouse gas emissions by $40 \%$ for 2030 and $80-95 \%$ by 2050 (Sandström et al., 2018).

\section{MATERIALS AND METHODS}

In this paper, we present an analysis of the current situation regarding sustainable food habits and consumer sophistication with environmental and social impact. In our research we want to assess the level of consumer awareness for sustainable food consumption and food waste through purchasing decisions among Slovak consumers.

The data were collected as the partial goal of the project funded by European Union with primary target to improve skills and competencies of adults on sustainable consumption of foods. The marketing research was conducted in partner countries with an existing long track record of influencing consumer behavior (Sweden, Denmark, and Austria) and those more recently engaged (Slovakia and Turkey). Data collection was realized in the period from March 2020 to April 2020. 
Questionnaire items were divided into logical dimensions. The representativeness of the sample was verified on the basis of the age and gender categories of the respondents corresponding to the national composition of the Slovak population. Age category is based on the generation group of the age group. Regarding to the extensive issues of the questionnaire, in our article we present only selected items that affect our focus of interest.

In order to achieve formulated objectives, diverse sources of information were processed and applied. The final data from questionnaire was processed and analyzed in MS Excel

TABLE 1 | Sociodemographic characteristics of respondents.

\begin{tabular}{|c|c|c|c|}
\hline & Categories & $\begin{array}{l}\text { Absolute } \\
\text { frequency }\end{array}$ & $\begin{array}{l}\text { Relative } \\
\text { frequency }\end{array}$ \\
\hline \multirow[t]{2}{*}{ Gender } & Female/woman & 153 & $51 \%$ \\
\hline & Male/man & 147 & $49 \%$ \\
\hline \multirow[t]{5}{*}{ Age group } & Generation Z & 21 & $7 \%$ \\
\hline & Millennials & 86 & $29 \%$ \\
\hline & Generation X & 85 & $28 \%$ \\
\hline & Baby Boomers & 90 & $30 \%$ \\
\hline & Silent & 18 & $6 \%$ \\
\hline \multirow{2}{*}{$\begin{array}{l}\text { Area of } \\
\text { living }\end{array}$} & Town & 201 & $67 \%$ \\
\hline & Rural area & 99 & $33 \%$ \\
\hline \multirow{3}{*}{$\begin{array}{l}\text { Household } \\
\text { income }\end{array}$} & Low (up to 500 Eur) & 13 & $4 \%$ \\
\hline & Medium (501 - 1,500 Eur) & 155 & $52 \%$ \\
\hline & High (more than 1,500 Eur) & 132 & $44 \%$ \\
\hline
\end{tabular}

Source: own processing and data collection. by using contingency tables. Statistical data processing was performed via XLStat. For a deeper analysis of the data and their significance, we used the following statistical tests: Chi-Square test of independence, Levene's test, Bartlett's test, Correspondence analysis and Kruskal-Wallis Test. For the scientific purpose of our study, we formulated the following assumptions:

- Assumption 1: There is a dependency between opinions on access to information and place of residence.

- Assumption 2: There is a dependency between the searching of information where and how food products are produced and the level of education.

- Assumption 3: There is a dependency between purchase of locally grown food and household income.

- Assumption 4: There exist differences in preference of preparing shopping list according to age generations.

The formulation of presented assumptions follows from the defined criteria in joint research.

We took advantage of a survey administration app (Google Forms) for the questionnaire procedure. The respondents were asked to participate in online environment by using social networks and e-mails. Several questionnaires were sent by using the postal system and filled in a printed version. Final number of the respondents from the Slovak Republic is 300 , as it can be seen in Table 1 where sociodemographic characteristics of the respondents are displayed.

The division of consumers into age generations differs in the professional literature and no consensus has yet been reached, so we decided to use the classification by Pew Research Center (Figure 1).

\section{The generations defined}

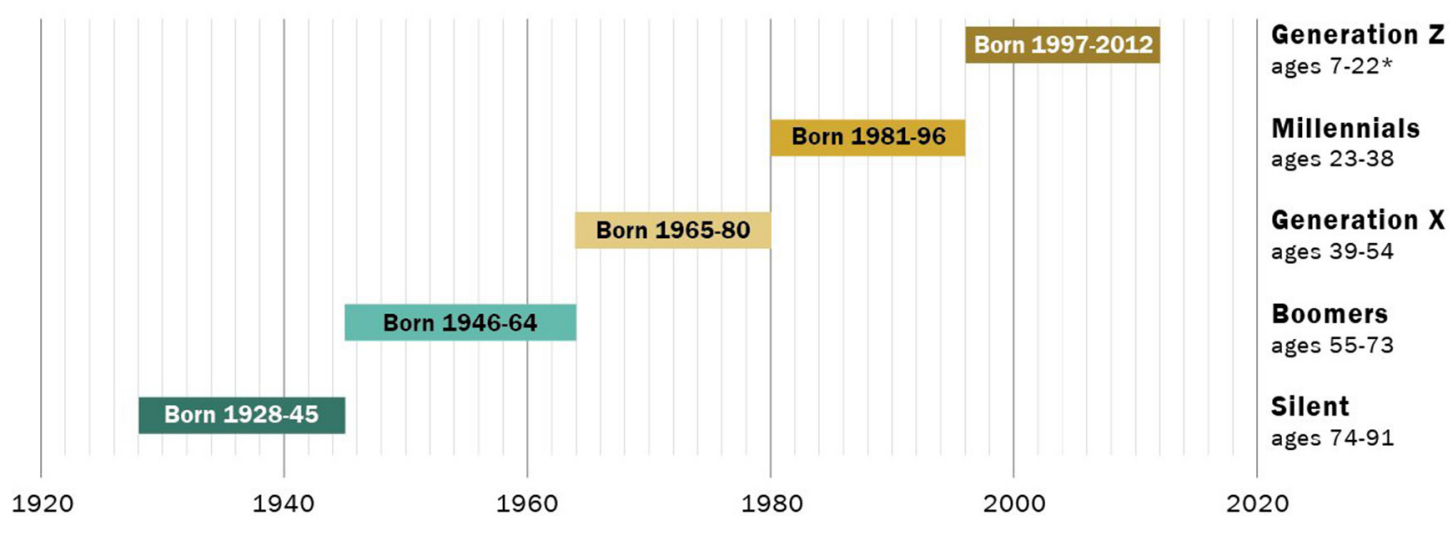

* No chronological endpoint has been set for this group. For this analysis, Generation Z is defined as those ages 7 to 22 in 2019 .

PEW RESEARCH CENTER
GENERATION AGE

IN 2019

Generation Z
ages $7-22^{*}$
Millennials
ages 23-38
Generation X
ages $39-54$
Boomers
ages 55-73
Silent
ages $74-91$
20




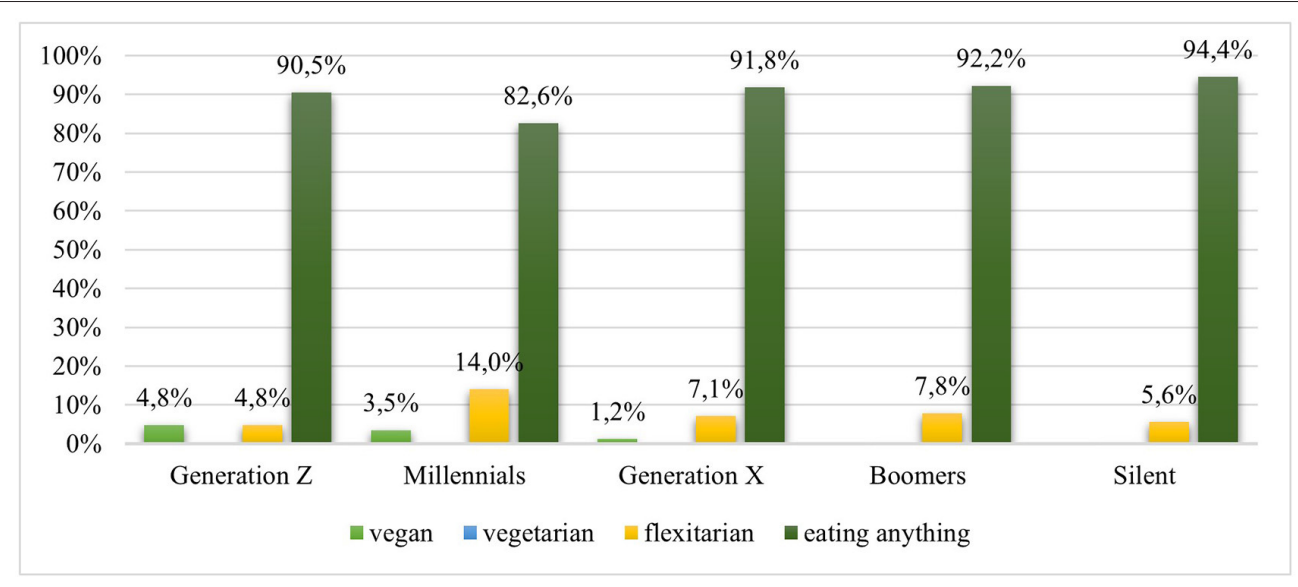

FIGURE 2 | Respondent eating habits according to age generations. Source: own processing and data collection.

\section{RESULTS}

We learn from various studies that people's eating habits are changing, and this is also a consequence of the application of a healthier eating lifestyle, but also a response to the negative environmental consequences of the production and consumption of certain types of food. This is the reason why we focused on the ways of respondents diet in relation to individual age generations in our analysis. In Figure 2 we see that most respondents belong to the group of people who eat everything, so meat is one of the main ingredients. In this case, the individual generations show us a kind of development over time. Respondents from generation "Silent" and "Boomers" are almost the same in their eating habits. The first vegans appear in Generation X (1.2\%) and their number is gradually growing. Millennials represent consumers for whom we can identify changed eating habits compared to older generations, because they represent people aged 25-40 who follow current trends, are influenced by the media, have created certain values and will influence future generations with their attitudes. On the positive side, millennials represent the smallest group of people "eating anything" and a significant share is shown by the group of flexiterians (14.0\%) and also vegans (3.5\%). Respondents from Generation $\mathrm{Z}$ are affected to some extent by their parents' eating patterns, nevertheless we can observe that the number of vegans shows the highest percentage. This generation is most influenced by global trends, especially social networks, which the content is more sustainable food consumption and a healthy diet. In the future, it will be interesting to see how this generation will develop.

Households are responsible for about half of food waste in Slovakia. So far, according to Eurostat data from 2016 on the amount of municipal waste, the Ministry of Agriculture and Rural Development of the Slovak Republic estimates that $\sim 180 \mathrm{~kg}$ per capita of food was wasted in Slovakia. That was the reason why in the next question we focused on how much food is thrown away according to individual types of food. As can be seen in Figure 3, we did not notice significant differences in the waste production of the four commodities, whose curves are almost identical. A more significant difference can be noted for bread and cereals, where a significant percentage of the respondents (17\%) admitted that they waste to a greater extent than $20 \%$. The reason is that this kind of food has a much shorter shelf life than other types of food, therefore, it is important for the consumer to take a much more rational approach when buying this commodity. In second place was waste from fruit and vegetables. The least respondents waste meat and animal products, which is a reflection of the higher price of these products.

Recently, the efforts of various environmental organizations in Slovakia have been growing to make people aware about their carbon footprint of food and learn to make the right decisions already when making a purchasing decision. Therefore, one of the items in the questionnaire was a question that asked whether respondents have access to information about which foods are more sustainable than others. After evaluating this question, we can state that a statistically equal share of positive and negative answers was demonstrated. Thirty-six percent of the respondents admitted that they have access to information, which they can easily find and understand it, and $36 \%$ of the respondents said that they do not agree that they have any opportunity to obtain such information. Also, a significant percentage of respondents (27\%) were neutral in their responses, i.e., they cannot assess whether they have access to such information. These results create space for even stronger support for the development of habits in the field of sustainable food consumption, as we consider well-processed and targeted information to be the first step toward progress to greater sustainability at the level of developed countries.

We assumed that people living in towns are more affected by various promotional activities, live a more hectic life and by not having the opportunity to grow their own food, that they will be more interested in a healthier lifestyle and seek information to a much greater extent. Therefore, we analyzed this question in more depth, from the perspective of the respondents living in towns and in rural areas. We have formulated the following Assumption 1, where we suppose a 


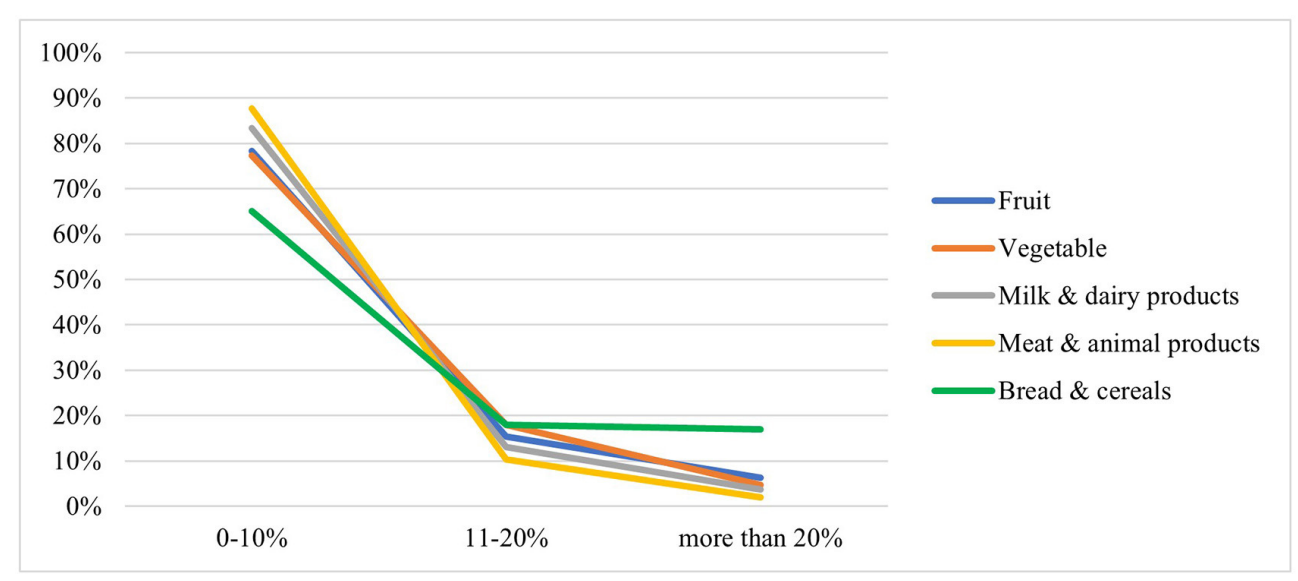

FIGURE 3 | Household food waste. Source: own processing and data collection.

TABLE 2 | Results of Chi-Square test of independence.

\begin{tabular}{lc}
\hline Chi-square (Observed value) & 0.674 \\
Chi-square (Critical value) & 9.488 \\
DF & 4 \\
$p$-value & 0.954 \\
Alpha & 0.05 \\
\hline
\end{tabular}

Source: own processing, XLStat.

dependency between opinions on access to information and place of residence, was statistically tested.

HO: The place of residence and access to information are independent.

H1: The place of residence and access to information are not independent.

We used the Chi-Square test of independence to determine whether there exists a relationship between two categorical variables (Table 2). The null hypothesis must be accepted because $p$-value (0.954) is higher than alpha level (0.05). Accordingly to these results, we conclude that there is no relationship between the place of residence and opinions on access to information about which foods are more sustainable than others. Subsequently, we performed a graphical analysis (Figure 4), where we can see very clearly that the opinions of the respondents living in towns are almost comparable to the answers of the respondents living in rural areas, as the curves on the radar graph are almost identical.

Through the following question, we tried to go deeper into the issue, where we focused on whether respondents search where and how food products they buy are produced. The aim of this question was to find out whether consumers are interested in the origin of the food and the process of production. These facts are crucial, especially in reducing the carbon footprint and sustainability throughout the supply chain. The majority of the respondents clearly stated that they are interested in where and how the food products they consume
TABLE 3 | Levene's test.

\begin{tabular}{lc}
\hline$F$ (Observed value) & 11.221 \\
$F$ (Critical value) & 2.313 \\
DF1 & 9 \\
DF2 & 32 \\
p-value (one-tailed) & 0.009 \\
Alpha & 0.05
\end{tabular}

Source: own processing, XLStat.

are produced- $-36 \%$ of the respondents totally agree and 34\% of the respondents agree with this statement. Negative attitude respectively disinterest expressed $17 \%$ of the total number of the respondents (Figure 5).

Regarding to the data obtained through this question and answers provided by the interviewees, we aimed to find out whether there is a dependence between the interest in where and how food products are produced in relation to the level of education of the respondents. We suppose that people's awareness in finding the right information is highly related to their level of education (Assumption 2). Subsequently, we created these hypotheses:

H0: There does not exist a dependence between the searching of information about food products and the level of education.

H1: There exists a dependence between the searching of information about food products and the level of education.

Statistical analysis of the dependence was carried out by using Levene's test (Table 3) and Bartlett's test (Table 4), providing the relevance and objectivity of the obtained results.

Based on the results shown in Tables 3, 4, it is stated that the null hypothesis must be rejected ( $p$-value is less than the alpha level $=0.05$ ), it indicates statistically significant dependence between searching information where and how food products are produced and the level of education. At the same time, we can conclude, the higher education of the respondents, the more positive answers were marked. Respondents with lower 


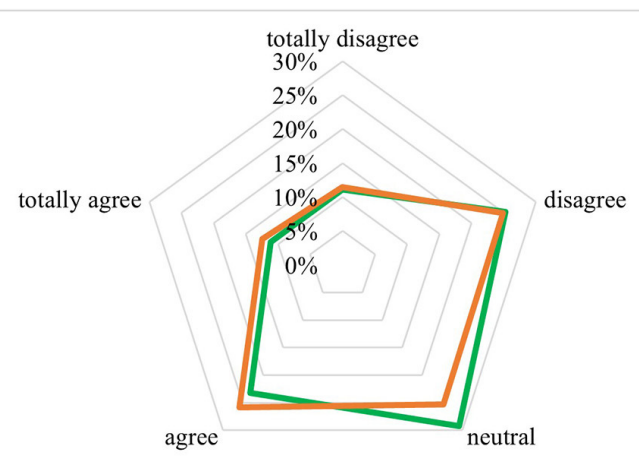

FIGURE 4 | Opinion on access to information according to place of living. Source: own processing and data collection.

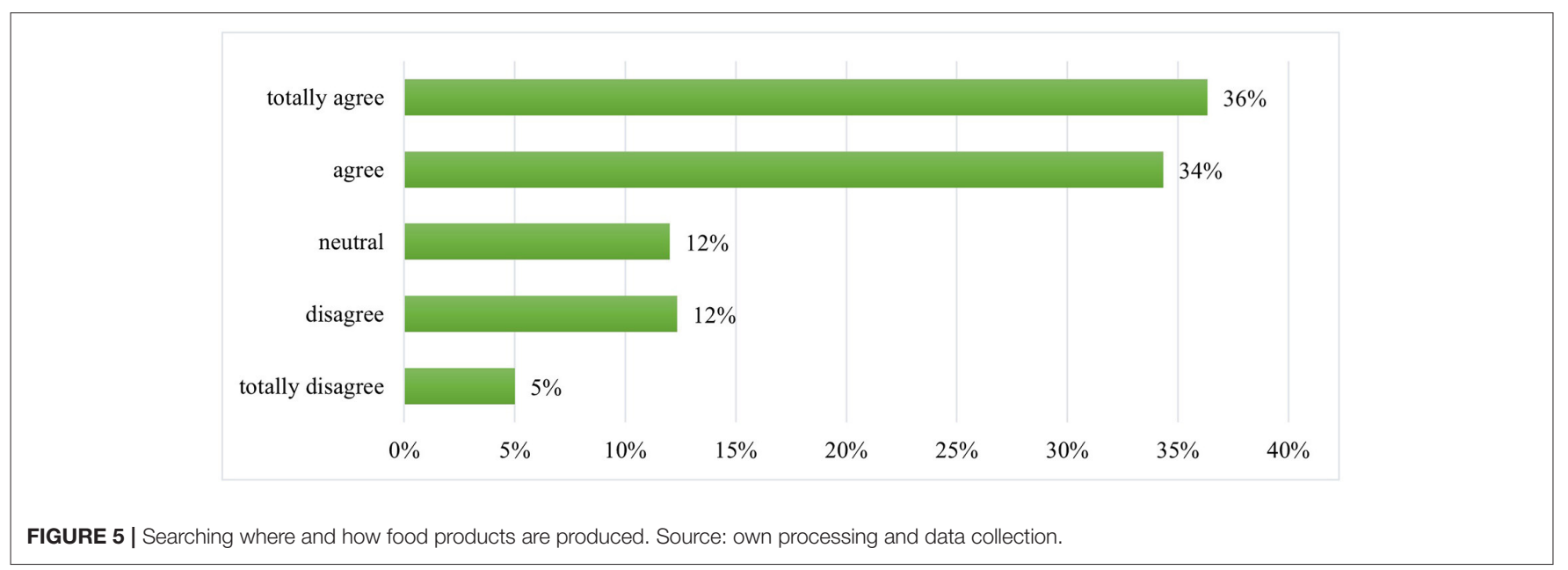

TABLE 4 | Bartlett's test.

\begin{tabular}{lc}
\hline Chi-square (Observed value) & 60.894 \\
Chi-square (Critical value) & 14.067 \\
DF & 9 \\
p-value (one-tailed) & $<0.0001$ \\
Alpha & 0.05 \\
\hline
\end{tabular}

Source: own processing, XLStat.

education are not interested in deliberately searching for such information. We can conclude that above mentioned Assumption 2 was confirmed.

Further question provides an important finding for our research, as we wanted to find out to what extent Slovak consumers prefer local food products. The preference for local products is also reflected in the support of the local economy and small growers, whose products qualitatively exceed imported food. The preference for local food production is also reflected in seasonal food consumption, which has a positive effect on reducing the carbon footprint of imported food. In general, we can say that local foods are a bit more expensive, and the consumer has to pay a higher price for such foods. That was the reason why we have put this question into deeper analysis.

When evaluating purchases of locally grown food with respect to household income, we set Assumption 3, where we assumed the dependence between purchase of locally grown food and household income. By determining the abovementioned assumption, we subsequently created a contingency table (Table 5).

When identifying whether there is significant correlation between two categorical variables, we used the Chi-Square test of independence (Table 6). Since the $p$-value (0.004) is less than the significance level (0.05), the null hypothesis must be rejected. Thus, we conclude that there is a relationship between purchase of locally grown food and household income.

To better display the analyzed dependencies, we applied a multivariate graphical technique designed to examine the relationships among categorical variables. Correspondence analysis (Figure 6) indicates the relative relationships between and within the two groups of variables, based on the data given in a contingency table. 
TABLE 5 | Contingency table of the household income and purchase of locally grown food.

\begin{tabular}{|c|c|c|c|c|c|c|}
\hline Household income & Totally disagree & Disagree & Neutral & Agree & Totally agree & Total \\
\hline Low & 1 & 5 & 2 & 4 & 1 & 13 \\
\hline Medium & 4 & 14 & 27 & 75 & 35 & 155 \\
\hline High & 7 & 6 & 27 & 55 & 37 & 132 \\
\hline Total & 12 & 25 & 56 & 134 & 73 & 300 \\
\hline
\end{tabular}

Source: own processing, XLStat.

TABLE 6 | Results of Chi-Square test of independence.

\begin{tabular}{lc}
\hline Chi-square (Observed value) & 22.463 \\
Chi-square (Critical value) & 15.507 \\
DF & 8 \\
$p$-value & 0.004 \\
Alpha & 0.05
\end{tabular}

Source: own processing, XLStat.

The points and distances between them in Figure 6 indicate the strength of the dependence between them, i.e., if the points are close to each other we speak about strong to very strong dependence and vice versa if the points have larger distances from each other, we consider about weak to very weak dependence between them. The willingness to purchase local products with regard to the amount of household income was very important for us also due to higher price of such foods. As can be seen from Figure 6, households with higher income have a neutral to highly positive attitude toward the purchase of locally grown food, what leads us to the conclusion that a household with a higher income is willing to pay a higher price for local food. Medium-income households are also largely inclined to purchase locally grown food, as evidenced by their close proximity to responses agree, neutral and totally agree. In the case of low-income households, a rather negative approach is reported. In order to increase the interest of low-income households, it is important to improve the availability of locally grown food even in lower price categories, which could be appeal to low-income households.

In the last presented question, the respondents were asked to express their opinion on question: "Do you make a shopping list before going food shopping?" The issue of the shopping list is largely related to the food waste itself. Ideally, every consumer should carefully consider what he really needs before entering the grocery shop. Excessive food purchases almost in every case lead to unjustified food waste. Figure 7 displays that the majority of the interviewees (73\%) agree that they make a shopping list before going food shopping, what we consider as a very positive result in progress against food waste. Only $12 \%$ of the respondents took a neutral stance and $15 \%$ of the respondents claim that they are not interested and have no time to create shopping lists.

We wanted to find out if the shopping list preferences differ according to the age of the respondents. This analysis for the assessment of Assumption 4 was carried out by the Kruskal-Wallis
Test, the results of which are given in Table 7 . The following hypotheses were tested:

H0: There do not exist differences in the answers given by different age generations.

H1: There exist differences in the answers given by different age generations.

Based on the theoretical level of significance, the null hypothesis related to the same choice of answer by age generations is rejected. Otherwise stated, we can confirm that there are statistically significant differences in responses associated with age generations at the level of alpha significance.

\section{DISCUSSION}

The principles of sustainable food consumption in Slovakia are gradually gaining public awareness and many companies and supply chains have also taken a responsible approach. Many consumers care about the sustainability of food products, although this positive attitude is not always translated into purchasing behavior. The goal of various environmental initiatives in Slovakia is to make people aware that food production is responsible for one-quarter of the world's greenhouse gas emissions. Eating is an important part of a person's overall ecological footprint. By a suitable choice of food, we can significantly reduce the burden on nature.

According to a Slovak nationwide representative survey carried out by the AKO agency for the Ministry of Agriculture and Rural Development in 2018, around 23\% of Slovaks admitted they threw away the leftovers. The survey suggests that people aged 23-49 years are wasting the most food. The share of wasting in households tends to increase with education and income. Every fifth Slovak admits that they waste food. An average Slovak citizen throws away $111 \mathrm{~kg}$ of food a year. Agriculture Ministry warns that wasting food also wastes natural resources, as well as people and their energy. It is not only irresponsible toward the environment, but also immoral toward people who cannot afford quality food. In the list of countries that waste food the most, Slovakia ranks eighth (TASR, 2018; The Slovak Spectator, 2018). Household food loss and waste within the EU27 is 8.3 million tons/year total, or an average of $113 \mathrm{~kg} /$ capita/year. This category is highly significant in the total picture of food waste and is the main focus of this project. Within the partner countries the numbers are:

- Austria: 41.94 kg/capita/year (Hietler and Pladerer, 2017) 


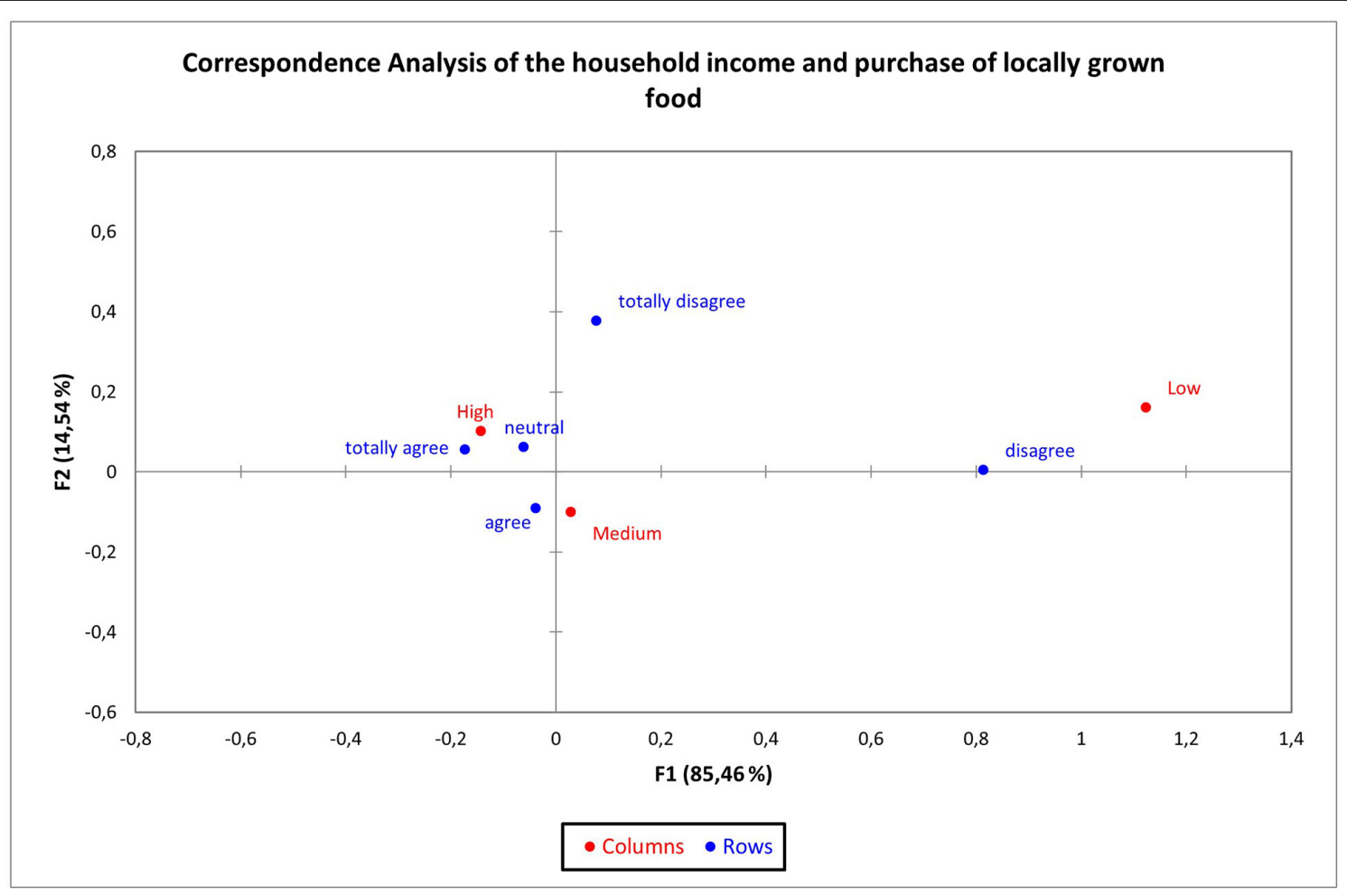

FIGURE 6 | Correspondence analysis of the household income and purchase of locally grown food. Source: own processing, XLStat.

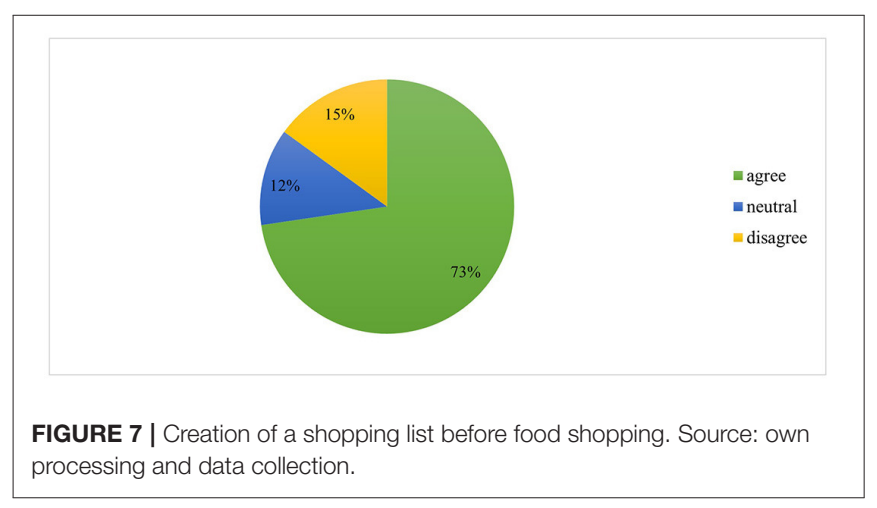

- Denmark: $42.95 \mathrm{~kg} / \mathrm{capita} /$ year (The Local, 2018)

- Sweden: $107 \mathrm{~kg} / \mathrm{capita} /$ year (Sörme et al., 2014)

- Slovakia: $111 \mathrm{~kg} / \mathrm{capita} /$ year (The Slovak Spectator, 2018)

- Turkey: Estimates are uncertain ranges from 76 to 132 $\mathrm{kg} / \mathrm{capita} /$ year (Salihoglu et al., 2018)

Within the last 4 years alone, the number of vegans, vegetarians and flexitarians in Europe has doubled, this group in total represent about $30.9 \%$ of the population-meaning that almost a third of all Europeans no longer consider themselves full meat-eaters anymore. Flexitarians represented the demographic experiencing the fastest growth of all, now making up $22.9 \%$ of Europeans (Ho, 2020). The number of vegans in Slovakia
TABLE 7 | Results of Kruskal-Wallis test.

\begin{tabular}{lc}
\hline$K$ (Observed value) & 16.3539 \\
$K$ (Critical value) & 5.1264 \\
DF & 2 \\
$p$-value (Two-tailed) & 0.003 \\
Alpha & 0.05
\end{tabular}

Source: own processing, XLStat.

was one of the topics of a recent survey of shopping trends in Slovakia. It turned out that in Slovakia live $1 \%$ of vegans, $2 \%$ of vegetarians, and almost $11 \%$ of people who reduce their meat consumption. The survey was conducted by the renowned agency Nielsen Admosphere on a sample of 500 respondents from the Slovak Internet population over 15 years of age. This was probably the first figure for the number of vegans in Slovakia and thus provided an interesting insight into our eating habits and the first opportunity to estimate the real numbers of this ever-growing group of people. In total, more than half a million people in Slovakia are looking for sustainable and considerate alternatives in their diet. This is a truly impressive figure for a country of this size, which also corresponds to the huge increase in the supply of vegan food and products in recent years (Nielsen Admosphere, 2016).

According to the Veganz nutrition study in 2020, it is estimated in Denmark are $2.7 \%$ vegans, $1.1 \%$ vegetarians, and 
$10.7 \%$ flexitarians. The flexitarian trend is the biggest in Austria (31.8\%) followed by $3.7 \%$ vegetarians and $1.6 \%$ vegans (Veganz, 2020). Sweden is one of the leading countries in vegan popularity as about $20 \%$ of younger Swedes think of themselves as being vegetarian or vegan (Skylare, 2019). Fortunately, as people's perception and consciousness have changed dramatically in recent years, living vegan or vegetarian is no longer a niche phenomenon. However, although consuming meat has been seen as a sign of financial well-being, the trend of veganism and vegetarianism is on the rise in developed countries. Turkey and Turkish people are famous for their love for meat but according to a new report (Euromonitor's latest Global Consumer Trends Report), vegetarianism has become a trend in Turkey as well (Dogan News Agency, 2019).

In the presented paper we formulated and evaluated four assumptions, which related to changing patterns of sustainable food consumption in Slovakia.

Assumption 1: There is a dependency between opinions on access to information and place of residence-was not confirmed.

Assumption 2: There is a dependency between the searching of information where and how food products are produced and the level of education-was confirmed.

Assumption 3: There is a dependency between purchase of locally grown food and household income-was confirmed.

Assumption 4: There exist differences in preference of preparing shopping list according to age generationswas confirmed.

As our results of the study are more than positive. We need to constantly raise awareness, but especially to formulate

\section{REFERENCES}

Berčík, J., and Gálová, J. (2013). "Selected aspects of sustainable issues in food chain," in Human Capital and Corporate Responsibility (Czestochowa: Sekcja Wydaw. WZ PCzest.), 7-26.

Black, I. (2010). Sustainability through anti-consumption. J. Consumer Behav. 9, 403-411. doi: $10.1002 / \mathrm{cb} .340$

Blay-Palmer, A. (2008). Food Fears: From Industrial to Sustainable Food Systems. Hampshire: Ashgate Publishing Limited.

Briceno, T., and Stagl, S. (2006). The role of social processes for sustainable consumption. J. Clean. Prod. 14, 1541-1551. doi: 10.1016/j.jclepro.2006.01.027

Castellani, V., Beylot, A., and Sala, S. (2019). Environmental impacts of household consumption in Europe: comparing process-based LCA and environmentally extended input-output analysis. J. Clean. Prod. 240:117966. doi: 10.1016/j.jclepro.2019.117966

Csillag, J., Petrović, A., Vozárová, V., Bilčík, M., BoŽiková, M., and Holota, T. (2019). Comparison of rheological properties of new and used biolubricants. Trends Agri. Eng. 1, 103-108.

Dogan News Agency (2019). Vegetarianism a Rising Trend Among Turks. Available online at: https://www.dailysabah.com/food/2019/08/06/vegetarianism-arising-trend-among-turks (accessed June 6, 2020).

Donati, M., Menozzi, D., Zighetti, C., Rosi, A., Zinetti, A., and Scazzina, F. (2016). Towards a sustainable diet combining economic, environmental and nutritional objectives. Appetite 106, 48-57. doi: 10.1016/j.appet.2016. 02.151 recommendations for re-education and to build and expand current food waste initiatives, focusing on new habits integrated into the lifestyle. Often, messages about the environmental consequences of adults' behavior can adversely affect behavior and may make people feel guilty. However, we do not think that negative scenarios are a good choice. Therefore, positive vision and messages based on real success stories need to be created and presented for behavior change. Finally, the key question that every consumer should ask himself is: "What can I do to really reduce my personal carbon footprint?"

\section{DATA AVAILABILITY STATEMENT}

The raw data supporting the conclusions of this article will be made available by the authors, without undue reservation.

\section{AUTHOR CONTRIBUTIONS}

$\mathrm{MH}$ responsible for data analysis and technical processing. $\mathrm{EH}$ responsible for the main idea and concept. LN responsible for literature overview. All authors contributed to the article and approved the submitted version.

\section{ACKNOWLEDGMENTS}

This manuscript was created within the project Assessing and Changing Adults' Behavior on Sustainable Consumption of Food (Project No: 2018-1-TR01-KA204-058739), which is implemented in the frame of the Erasmus+ KA2 Strategic Partnership for Adult Education.

Fanzo, J. (2019). Healthy and sustainable diets and food systems: the key to achieving sustainable development goal 2? Food Ethics 4, 159-174. doi: 10.1007/s41055-019-00052-6

Hietler, P., and Pladerer, C. (2017). Abfallvermeidung in der österreichischen Lebensmittelproduktion. Available online at: https://www.nachhaltigkeit. steiermark.at/cms/dokumente/12592682_139338025/a56135dd/

153Abfallvermeidung\%20in\%20der\%20Lebensmittelproduktion.pdf (accessed March 15, 2021).

Higgs, S., and Thomas, J. (2016). Social influences on eating. Curr. Opin. Behav. Sci. 9, 1-6. doi: 10.1016/j.cobeha.2015.10.005

Ho, S. (2020). Europe: Over 20\% Now Flexitarian \& Number of Vegans Doubles, According to New Study. Available online at: https://www.greenqueen.com.hk/ europe-over-20-now-flexitarian-number-of-vegans-doubles-according-tonew-study/ (accessed June 2, 2020).

Ivanova, D., Stadler, K., Steen-Olsen, K., Wood, R., Vita, G., Tukker, A., et al. (2015). Environmental impact assessment of household consumption. J. Indus. Ecol. 19, 1-11. doi: 10.1111/jiec.12371

Kalbar, P. P., Birkved, M., Hauschild, M., Kabins, S., and Nygaard, S. E. (2018). Environmental impact of urban consumption patterns: drivers and focus points. Resourc. Conserv. Recycl. 137, 260-269. doi: 10.1016/j.resconrec.2018.06.019

Khan, M. I., Khan, S., Haleem, A., and Javaid, M. (2018). "Prioritising barriers towards adoption of sustainable consumption and production practices using TOPSIS," in IOP Conf. Series: Materials Science and Engineering. (Lucknow: IOP Publishing), 1-5. 
Lee, K. M. (2014). Predictors of sustainable consumption among young educated consumers in Hong Kong. J. Int. Consumer Markets 26, 217-238. doi: 10.1080/08961530.2014.900249

Malodia, S., and Bhatt, A. S. (2019). Why should I switch off: understanding the barriers to sustainable consumption? Vision J. Bus. Perspect. 23, 134-143. doi: 10.1177/0972262919840197

Matharu, M., Jain, R., and Kamboj, S. (2021). Understanding the impact of lifestyle on sustainable consumption behavior: a sharing economy perspective. Manag. Environ. Qual. 32, 20-40. doi: 10.1108/MEQ-02-2020-0036

McDonald, S., Oates, C. J., Alevizou, P. J., Young, C. W., and Hwang, K. (2012). Individual strategies for sustainable consumption. J. Market. Manag. 28, 445-468. doi: 10.1080/0267257X.2012.658839

Mihina, Š., Pšenka, M., Järvi, M., Šístková, M., KaŽimírová, V., and Holota, T. (2018). Noise analysis at different technological solutions of milking devices. Appl. Eng. Agri. 34, 921-927. doi: 10.13031/aea.12717

Mont, O., and Plepys, A. (2008). Sustainable consumption progress: should we be proud or alarmed? J. Clean. Prod. 16, 531-537. doi: 10.1016/j.jclepro.2007.01.009

Nielsen Admosphere (2016). TS Slováci na jedle radi ušetria, ale sú aj ochotní si za kvalitu priplatit a majú záujem o zdravý životný štýl. Available online at: https://www.nielsen-admosphere.sk/press/ts-slovaci-na-jedle-radi-usetriaale-su-aj-ochotni-si-za-kvalitu-priplatit-a-maju-zaujem-o-zdravy-zivotnystyl/ (accessed March 11, 2021).

OECD (2018). Agricultural Policy Monitoring and Evaluation 2018. Paris: OECD Publishing. doi: 10.1787/agr_pol-2018-en

Our World in Data (2020). Environmental Impacts of Food Production. Available online at: https://ourworldindata.org/environmental-impacts-offood\#citation (accessed March 10, 2021).

Pew Research Center (2019). Defining Generations: Where Millennials End and Generation Z Begins. Available online at: https://www.pewresearch.org/facttank/2019/01/17/where-millennials-end-and-generation-z-begins/ (accessed February 10, 2020).

Quoquab, F., and Mohammad, J. (2017). "Managing sustainable consumption: is it a problem or panacea?" in Sustainable Economic Development, eds W. L. Filho, D. M. Pociovalisteanu, and A. Q. Al-Amin (Cham: Springer), 115-125.

Reisch, L., Eberle, U., and Lorek, S. (2013). Sustainable food consumption: an overview of contemporary issues and policies. Sustainabil. Sci. Pract. Pol. 9, 7-25. doi: 10.1080/15487733.2013.11908111

Salihoglu, G., Salihoglu, N. K., Ucaroglu, S., and Banar, M. (2018). Food loss and waste management in Turkey. Bioresour. Technol. 248, 88-99. doi: 10.1016/j.biortech.2017.06.083

Sandström, V., Valin, H., Krisztin, T., Havlík, P., Herrero, M., and Kastner, T. (2018). The role of trade in the greenhouse gas footprints of EU diets. Glob. Food Security 19, 48-55. doi: 10.1016/j.gfs.2018.08.007

Sener, A., and Hazer, O. (2008). Values and sustainable consumption behavior of women: a Turkish sample. Sustain. Dev. 16, 291-300. doi: 10.1002/sd.329

Sharma, R., and Jha, M. (2017). Values influencing sustainable consumption behaviour: exploring the contextual relationship. J. Bus. Res. 76, 77-88. doi: 10.1016/j.jbusres.2017.03.010

Sharma, R., Nguyen, T. T., and Grote, U. (2018). Changing consumption patterns-drivers and the environmental impact. Sustainability 10:4190. doi: $10.3390 /$ su10114190
Skylare, E. (2019). Food Makes Youth Climate Superheroes. Available online at: https://www.norden.org/en/news/food-makes-youth-climate-superheroes (accessed June 3, 2020).

Sörme, L., Johansson, M., and Stare, M. (2014). Mängd mat och dryck via avloppet - en enkätundersökning i svenska hushåll. Naturvårdsverket. Available online at: https://www.naturvardsverket.se/Documents/ publikationer6400/978-91-620-6624-6.pdf?pid=13805 (accessed March $11,2021)$.

TASR (2018). V košoch slovenských domácností končia tony potravín ročne. Available online at: https://ekonomika.sme.sk/c/20830591/plytvaniepotravinami-zdravie-potraviny-jedlo-matecna.html (accessed March 11, 2021).

The Local (2018). Danish Consumers Reduced Food Waste by 14,000 Tonnes in Six Years. Available online at: https://www.thelocal.dk/20180418/danishconsumers-reduced-food-waste-by-14000-tonnes-in-6-years/ (accessed March 16, 2021).

The Slovak Spectator (2018). Slovaks Throw Away More Than $100 \mathrm{~kg}$ of Food. Available online at: https://spectator.sme.sk/c/20832422/ slovaks-throw-away-more-than-100-kg-of-food.html (accessed March 10, 2021).

Tukker, A., Huppes, G., Guinée, J., Heijungs, R., de Koning, A., van Oers, L., et al. (2006). Environmental Impact of Products (EIPRO): Analysis of the Life Cycle Environmental Impacts Related to the Final Consumption of the EU-25. Brussels: JRC.

Vasilová, M. (2013). "Sustainable development as a part of marketing education," in Vedecké state Obchodnej fakulty, eds P. Drábik, I. Hlavatý, and P. Červenka (Bratislava: Vydavatelstvo Ekonóm), 604-614.

Veganz (2020). Veganz Nutrition Study 2020. Available online at: https:/veganz.com/blog/veganz-nutrition-study-2020/ (accessed May 10, 2020).

Verain, M. C. D., Bartels, J., Dagevos, H., Sijtsema, S. J., Onwezen, M. C., and Antonides, G. (2012). Segments of sustainable food consumers: a literature review. Int. J. Consumer Stud. 36, 123-132. doi: 10.1111/j.1470-6431.2011.01082.x

Verain, M. C. D., Dagevos, H., and Antonides, G. (2015). Sustainable food consumption. Product choice or curtailment? Appetite 91, 375-384. doi: 10.1016/j.appet.2015.04.055

Wang, P., Liu, Q., and Qi, Y. (2014). Factors influencing sustainable consumption behaviors: a survey of the rural residents in China. J. Clean. Prod. 63, 152-165. doi: 10.1016/j.jclepro.2013.05.007

Conflict of Interest: The authors declare that the research was conducted in the absence of any commercial or financial relationships that could be construed as a potential conflict of interest.

Copyright (C) 2021 Holotová, Horská and Nagyová. This is an open-access article distributed under the terms of the Creative Commons Attribution License (CC BY). The use, distribution or reproduction in other forums is permitted, provided the original author(s) and the copyright owner(s) are credited and that the original publication in this journal is cited, in accordance with accepted academic practice. No use, distribution or reproduction is permitted which does not comply with these terms. 